Article

\title{
Comparative In Vitro Study of the Bond Strength of Composite to Carbon Fiber Versus Ceramic to Cobalt-Chromium Alloys Frameworks for Fixed Dental Prostheses
}

\author{
Rocio Cascos-Sanchez ${ }^{1}$, Pedro Molinero-Mourelle ${ }^{1, *}$ (D), Rocio Ortega ${ }^{2}$, \\ Ruben Agustin-Panadero ${ }^{3}{ }^{\mathbb{D}}$, Jaime Del Rio Highsmith ${ }^{1}$ and Miguel Gomez-Polo ${ }^{1}$ \\ 1 Department of Conservative Dentistry and Orofacial Prosthetics, Faculty of Dentistry, \\ Complutense University of Madrid, 28040 Madrid, Spain; rcascos@ucm.es (R.C.-S.); \\ jrh@odon.ucm.es (J.D.R.H.); mgomezpo@ucm.es (M.G.-P.) \\ 2 Department of Prosthetic Dentistry, Faculty of Dentistry, European University of Madrid, \\ 28670 Madrid, Spain; rocio.ortega@universidadeuropea.es \\ 3 Department of Stomatology, Faculty of Medicine and Dentistry, University of Valencia, 46010 Valencia, Spain; \\ ruben.agustin@uv.es \\ * Correspondence: pedromol@ucm.es
}

Received: 2 June 2020; Accepted: 13 July 2020; Published: 16 July 2020

\begin{abstract}
Purpose: The aim of this comparative in vitro study was to assess the bond strength and mechanical failure of carbon-fiber-reinforced composites against cobalt-chrome structures with ceramic veneering. Materials and methods: A total of 24 specimens (12 per group) simulating dental prosthetic frameworks were fabricated. The experimental specimens were subjected to a thermocycling aging process and to evaluate bond strength. All specimens were subjected to a three-point bending test to fracture using a universal testing machine. Results: The cobalt-chrome/ceramic group yielded a bond strength value of $21.71 \pm 2.16 \mathrm{MPa}$, while the carbon-fiber-reinforced composite group showed $14.50 \pm 3.50 \mathrm{MPa}$. The failure assessment reported statistical significance between groups. Although carbon-fiber-reinforced composite group showed lower bond strength values, the chipping incidence in this group was as well lower. Conclusions: The chrome-cobalt/ceramic group showed greater bonding strength compared to the carbon-fiber-reinforced composite; most of the fractures within the cobalt-chrome/ceramic group, had no possibility of direct clinical repair.
\end{abstract}

Keywords: bond strength; $\mathrm{Co}-\mathrm{Cr}$ alloy; carbon fiber; metal ceramic; fiber-reinforced composite; adhesion; three-point bend test; flexural properties

\section{Introduction}

Computer-aided design/computer-aided manufacturing (CAD/CAM) technology in dental medicine has allowed for the development of new biomaterials with the manufacturing of homogeneous prosthetic structures. Carbon-fiber-reinforced composite (CFRC) is a highly biocompatible material composed by $99.9 \%$ chemically pure carbon filaments with diameters of 5-10 $\mu \mathrm{m}$, embedded in an epoxy resin matrix producing braided meshes with 5000 to 8000 fibers [1]. This is about $58 \%$ of its weight and $47 \%$ of its volume. This composition provides excellent mechanical properties, such as high resistance to fatigue, fracture, abrasion and temperature. Moreover, it presents a low specific weight, thermal expansion coefficient, electrical conductivity and a good buffering of vibration forces [1-6]. CFRC has been mainly used in fixed dental prostheses (FDPs) and framework manufacturing $[7,8]$. 
In implant prosthodontics, the lack of mechanoreception and proprioception of partially and edentulous ridges implies that CFRC may be particularly favorable for these indications due to its good biomechanical capacity to absorb occlusal forces [1,9].

Compared to metal alloys, this material has advantages, such as, low specific weight, better flexural strength and an excellent chemical adhesion to the veneering resin [1-6]. Furthermore, CFRC could be presents in better biomechanical properties in terms of bone resorption around implants compared to metal frameworks, due its elastic properties comparable to dentin $[1,9,10]$.

Despite the recent developments on CAD/CAM materials, metal-based restorations are still considered the gold standard for implant-supported fixed restorations due to their high mechanical resistance and the excellent clinical performance in the medium- and long-term follow-up [11-14].

Over the last 20 years, with the increase of the price of gold, cobalt-chrome (Co-Cr) alloy has gained importance in metal-ceramic restorations because of its excellent mechanical properties, durability, affordability, absence of nickel, and resistance to corrosion [15-18].

Although Co-Cr-implant-supported restorations present high success rates, they are not exempt from complications, being one of the most frequent ceramic chipping [19-25]. The bond strength between the ceramic veneering and the underlying metal framework is a key factor linked to the success and survival of these restorations [26-28]. In a preclinical scenario, several methods have been proposed to determine the bond strength between materials, being one of the most used the 3-point bend test $[29,30]$.

Considering technical complications, the use of CRFC may present advantages over conventional restorations, where the chemical and mechanical bonding of organic components increases the bonding strength between the two materials, reducing the possibility of chipping.

The black color aspect of the CRFC is one of the disadvantages that this material presents. However, it can be covered using opaque layers masking the surface of prosthetic structures with good results [31] due to the optical properties that provide composite resins and the variety of dyes, intensities, values, existing opacities and translucencies.

Therefore, the aim of this in vitro study was to assess and compare the bond strength and the fracture behavior between metal-ceramic frameworks and CRFC frameworks. The first null hypothesis was that there would be no difference between bond strength among groups. The second null hypothesis was that the materials tested did not have an influence on the fracture type.

\section{Materials and Methods}

A sample size of 12 was calculated for each group, determined according to similar studies [28-32]. The standard deviation (S) was set at 4.40 and the alpha error (E) at 1.90. It was based on the following formula:

$$
N=\frac{t_{N-1}^{2} \times S^{2}}{E^{2}}
$$

A total of 24 specimens were made: 12 cobalt-chrome structures with ceramic veneering $(\mathrm{Co}-\mathrm{Cr})$ and 12 carbon-fiber structures veneered with composite resin (CFRC).

All the studied specimens were designed and manufactured according to UNE-EN ISO 178:2010 standards [33], following the manufacturer's specifications and by the same dental technician. A digital design of the $\mathrm{Co}-\mathrm{Cr}$ and CFRC frameworks was created using computer software (Dental System ${ }^{\circledR} 3$ Shape Designing Software ${ }^{\circledR}$ V.2017, 3Shape, Copenhagen, Denmark) with dimensions of $35 \times 10 \times$ $2 \mathrm{~mm}$. The generated Standard Tesselaction Language (STL) file was processed by a 5-axis milling machine (S2, VHF Camfacture AG ${ }^{\circledR}$, Ammerbuch, Germany), Table 1 and the specimens were made from Co-Cr (Easy Disc, Starbond ${ }^{\circledR}$, S\&S Scheftner GmbH, Mainz, Germany) and CFRC (Bio carbon tablet, MICRO MEDICA SRL ${ }^{\circledR}$, Robbio, Italy) CAD/CAM discs. Once the framework manufacturing had finished, all specimens were evaluated for the required 2-mm-thickness using a digital caliper (DC01 Digital Caliper Carbon Fiber, TackLife, Shenzhen, China) 
Table 1. Composition by percent mass of Co-Cr alloy.

\begin{tabular}{cc}
\hline Component & Percentage (\%) \\
\hline Co & $61 \%$ \\
$\mathrm{Cr}$ & $27.5 \%$ \\
$\mathrm{~W}$ & $8.5 \%$ \\
$\mathrm{Si}$ & $1.6 \%$ \\
$\mathrm{C}, \mathrm{Mn}, \mathrm{Fe}$ & $<1 \%$ \\
\hline
\end{tabular}

\subsection{Specimen Fabrication}

\subsubsection{Co-Cr Specimen Processing}

The Co-Cr specimens were sandblasted with $110 \mu \mathrm{m}$ aluminum oxide $\left(\mathrm{Al}_{2} \mathrm{O}_{3}\right)$, particles (Basic Classic, Renfert ${ }^{\circledR} \mathrm{GmbH}$, Hilzingen, Germany) for $15 \mathrm{~s}$ at a pressure of $200 \mathrm{kPa}$ at a distance of $10 \mathrm{~mm}$ and were then cleaned ultrasonically for $5 \mathrm{~min}$. The specimens were then placed in a dental ceramic furnace (Austromat 624 Oral Design, Dekema ${ }^{\circledR}$, Freilassing, Germany) for degassing and oxidation treatment at $990{ }^{\circ} \mathrm{C}$ before the ceramic application. A bonding agent (SR Link $5 \mathrm{ml}$, Ivoclar Vivadent ${ }^{\circledR}$, Schaan, Liechtenstein), opaquer, four layers of body ceramic (E.max Ceram, Ivoclar Vivadent ${ }^{\circledR}$, Schaan, Liechtenstein) and glazing layer were applied followed the recommendations of the manufacturer to achieve a total thickness of $2 \mathrm{~mm}$. All specimens were fired 5 times during the veneering process in a ceramic furnace (Austromat 624 Oral Design, Dekema ${ }^{\circledR}$, Freilassing, Germany). Table 2.

Table 2. Firing schedules of veneering procedure for $\mathrm{Co}-\mathrm{Cr}$ group in accordance with manufacturer and laboratory instructions [34].

\begin{tabular}{cccccc}
\hline Program & $\begin{array}{c}\text { Preheating } \\
\left({ }^{\circ} \mathbf{C}\right)\end{array}$ & $\begin{array}{c}\text { Drying Time } \\
(\mathbf{m i n})\end{array}$ & $\begin{array}{c}\text { Heating Rate } \\
\left({ }^{\circ} \mathbf{C} / \mathbf{m i n}\right)\end{array}$ & $\begin{array}{c}\text { Maximum } \\
\text { Temp. }\left({ }^{\circ} \mathbf{C}\right)\end{array}$ & $\begin{array}{c}\text { Total Time } \\
(\mathbf{m i n})\end{array}$ \\
\hline oxidation & 650 & 2 & 55 & 990 & 17 \\
metal bond & 550 & 3 & 80 & 980 & 15 \\
opaquer & 550 & 3 & 80 & 930 & 15 \\
body porcelain & 580 & 3 & 45 & 890 & 17 \\
glaze & 600 & 3 & 55 & 890 & 14 \\
\hline
\end{tabular}

\subsubsection{CFRC Specimens Processing}

The CFRC specimens' group were first sandblasted with $110 \mu \mathrm{m}$ aluminum oxide particles (Renfert ${ }^{\circledR}$, Hilzingen, Germany) for $15 \mathrm{~s}$ with a pressure of $200 \mathrm{kPa}$ at a $10 \mathrm{~mm}$ distance and were cleaned ultrasonically for $5 \mathrm{~min}$. A bonding agent (BioXfill, Micromedica SRL ${ }^{\circledR}$, Robbio, Italy) was applied on all specimens, followed by an opaquer layer and four resin composite layers (1 dentin layer, 1 translucent layer and 2 incisal layers) (SR Nexco Paste, Ivoclar Vivadent ${ }^{\circledR}$, Schaan, Liechtenstein) to obtain a thickness of $2 \mathrm{~mm}$. All layers were light-cured (HiLite power 3D, Kulzer ${ }^{\circledR} \mathrm{GmbH}, \mathrm{Hanau}$, Germany) for $180 \mathrm{~s}$ following the manufacturer's recommendations. Subsequently, all specimens from the CFRC group were polished using universal polishing paste (Ivoclar Vivadent ${ }^{\circledR}$, Schaan, Liechtenstein) in the polisher (R-080160, Mestra ${ }^{\circledR}$, Talleres mestraitúa, S.L., Bilbao, Spain).

After their manufacture, the specimens were measured in their length, width and thickness by a digital caliper (Tacklife-DC01, Kinnek Business Solutions LLC, New York, NY, USA), to ensure their standardization. To verify the thickness, three points, the two ends and the central area were measured. A discrepancy of $\pm 0.2 \mathrm{~mm}$ was allowed in relation to the thickness of the specimens.

\subsection{Thermocycling}

The experimental groups were subjected to a 10,000-cycle thermocycling process according to ISO TS 11405 standards [35] in distilled water at $5{ }^{\circ} \mathrm{C}$ and $55^{\circ} \mathrm{C}$, for $20 \mathrm{~s}$ with a 10-s dwell time (VA55, EuroOrtodoncia, Madrid, Spain). After the thermocycling process, all specimens were examined under 
an optical microscope (Telecentric Objective 1:1, Jos. Schneider Optische Werke GmbH, Bad Kreuznach, Germany) at $4 \times$ magnification Toupview V.x643.7.6701 (Toupview, ToupTek, ToupTek Photonics Co., Ltd, Hangzhou, China) to verify that there were no alterations in the frameworks or veneering material.

\subsection{Mechanical Testing}

All specimens were subjected to a three-point bending test to fracture using a universal testing machine (Zwick/Roell BT1FR2. 5TS.D14, 179392, VA27; Zwick/Roel, Ulm, Germany) in accordance with ISO 14125:1998 [36] and ISO 178:2010 standards [33] (Figure 1).

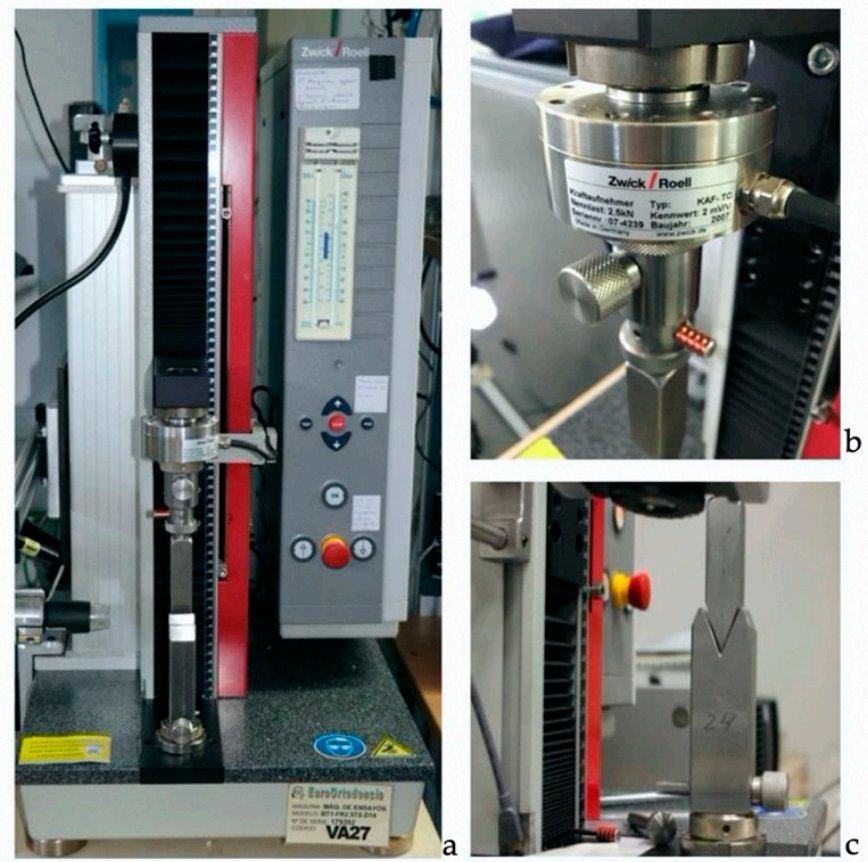

Figure 1. (a) Universal testing machine. The machine consists of (b) a load cell, in charge of measuring pressure and traction; and a motor, in charge of placing the cell at the appropriate distance. In addition, it consists of the (c) supports in charge of simulating 3-point bend test.

For the test, a holder with a distance between its supports of $32 \mathrm{~mm}$ was used in accordance with the ISO 178:2010 standard [33]. A preload of 0.2 $\mathrm{N}$ was established at an E-module speed and a test speed of $1 \mathrm{~mm} / \mathrm{min}$, in environmental conditions of $20^{\circ} \mathrm{C}$. A constant force with a speed of $1 \mathrm{~mm} / \mathrm{min}$ was applied in the center of the specimen up to a maximum force of $2500 \mathrm{~N}$ (at an equidistant point between the supports) or a maximum of 10-mm deformation.

Strain-stress curves and a magnification video were registered for all the samples during the bending test by using testXpert ${ }^{\circledR}$ II V143 software (Zwick/Roell, Ulm, Germany) and obtained data were recorded.

\subsection{Failure Assessment}

All the specimens were evaluated by using naked-eye assessment, tactile-probe assessment and under the optical microscope at $4 \times$ resolution, $(4912 \times 3684$ pixels $)$ to determine the fracture type as follows: adhesive (between the framework and covering material), cohesive (entirely within the framework or coating material) or mixed (a combination of adhesive and cohesive failure) [27-32,37].

\subsection{Data Analysis}

Statistical analysis was performed using IBM-SPSS-22 software (SPSS Statistics v 22.0, IBM Corp ${ }^{\circledR}$, Armonk, NY, USA). The mean values and standard deviations (SD) of the results were determined 
and to compare the goodness of fit to the normal distribution of the variables, the Shapiro-Wilk test was performed. The quantitative and qualitative variables were statistically analyzed using the Mann-Whitney $U$ test and the chi-squared test $\left(X^{2}\right)$, respectively. The statistical significance was established at $\leq 0.05$, except in the Shapiro-Wilk test that was established as $\alpha=0.01$. $p$-values of less than 0.5 were considered as statistically significant differences, except in the Shapiro-Wilk test, being $p=0.01$.

\section{Results}

Using Q-Q graphs of normality (Figure 2) and the Shapiro-Wilk test, it was verified that the data fit the Gauss model of normality $(p>0.05)$. The statistical normality fit was confirmed, which allowed the use of a parametric test as the statistical method of comparison between groups. All the studied variables were sufficiently close to the Gaussian normality model.

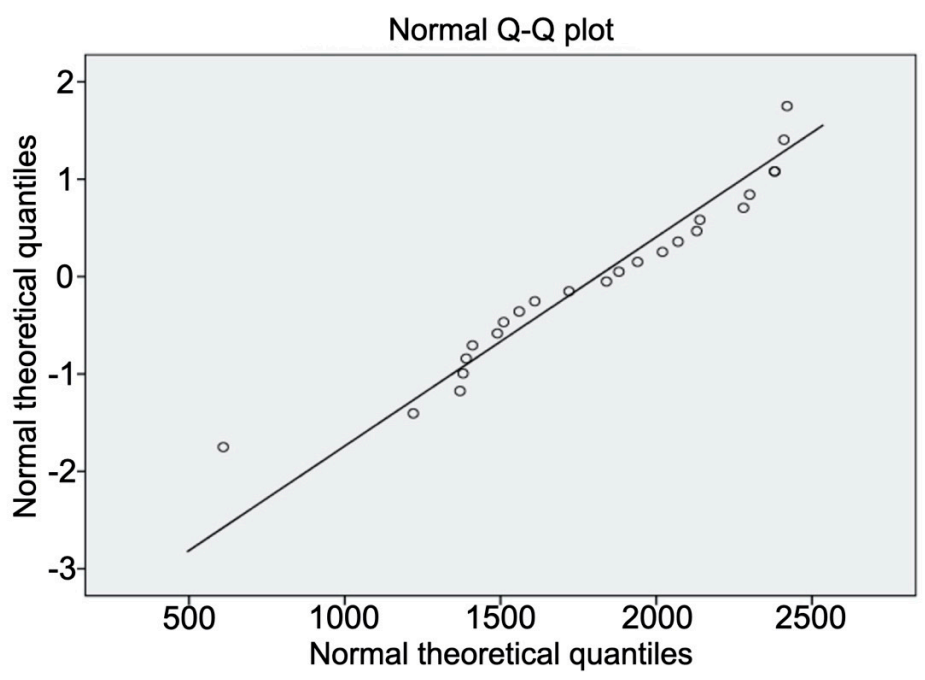

Figure 2. Representative $Q-Q$ plot for bond strength confirming the trend towards normality of the sample.

Statistically significant differences $(p<0.01)$ were observed in the bond strength values following the Mann-Whitney U test, obtaining higher values in the Co-Cr control group ( $21.71 \pm 2.16 \mathrm{MPa})$ against the CFRC test group (14.50 $\pm 3.50 \mathrm{MPa})$. The highest value $(24.20 \mathrm{MPa})$ was found in the $\mathrm{Co}-\mathrm{Cr}$ group while the lowest value (6.10 MPa) was observed in the CFRC group (Figure 3).

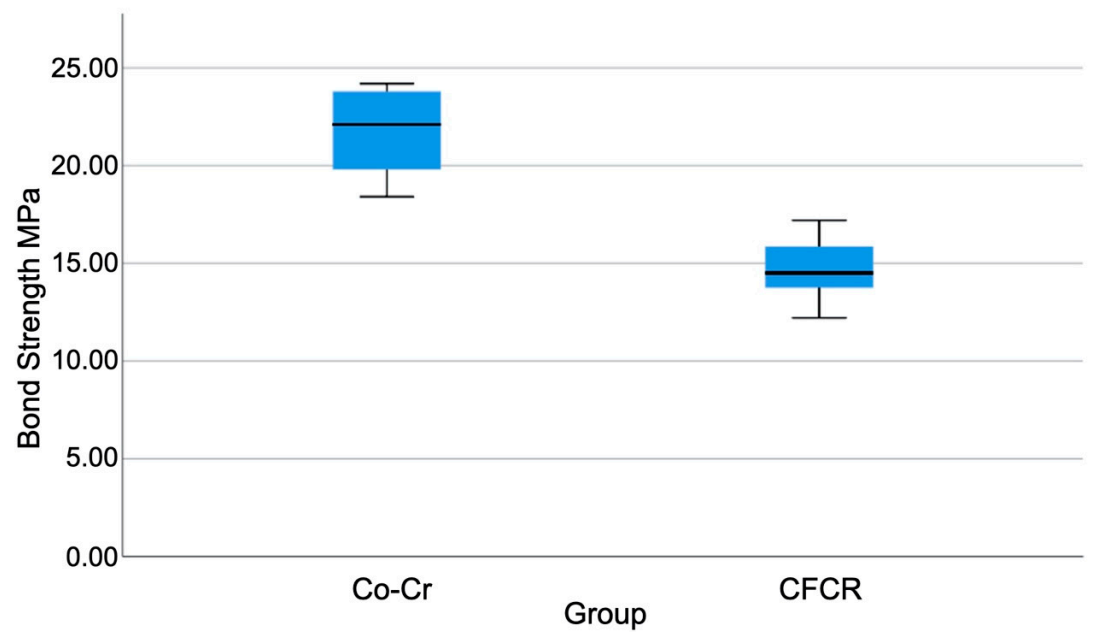

Figure 3. Representative box plot for bond strength according to the studied materials. 
Force-displacement diagrams show the mechanical behavior of the groups (Figure 4). The CFRC curves show a parabolic trend deviating from the straight line, indicating an elastic deformation of the material. The $\mathrm{Co}-\mathrm{Cr}$ group showed a linear curve trend, indicating a nonlinear elasticity of the material and consequent plastic deformation.

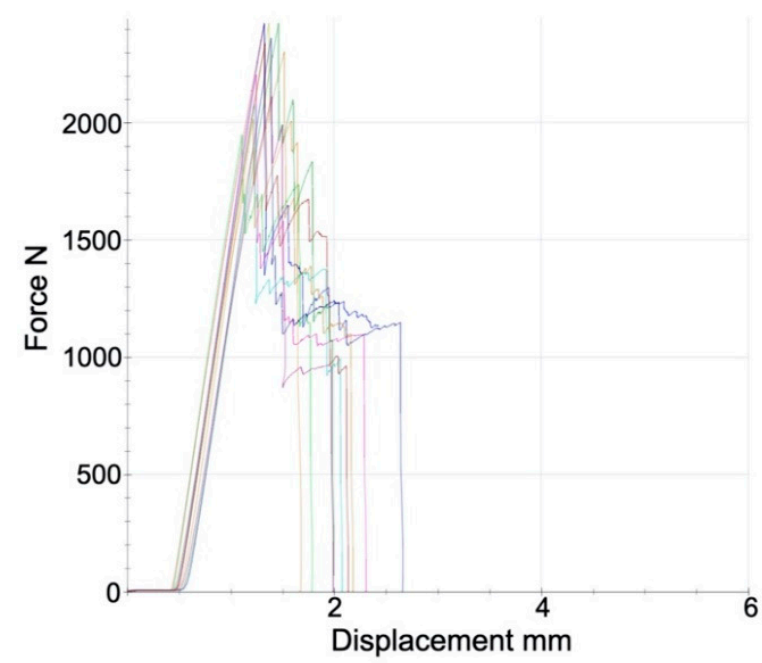

(a)

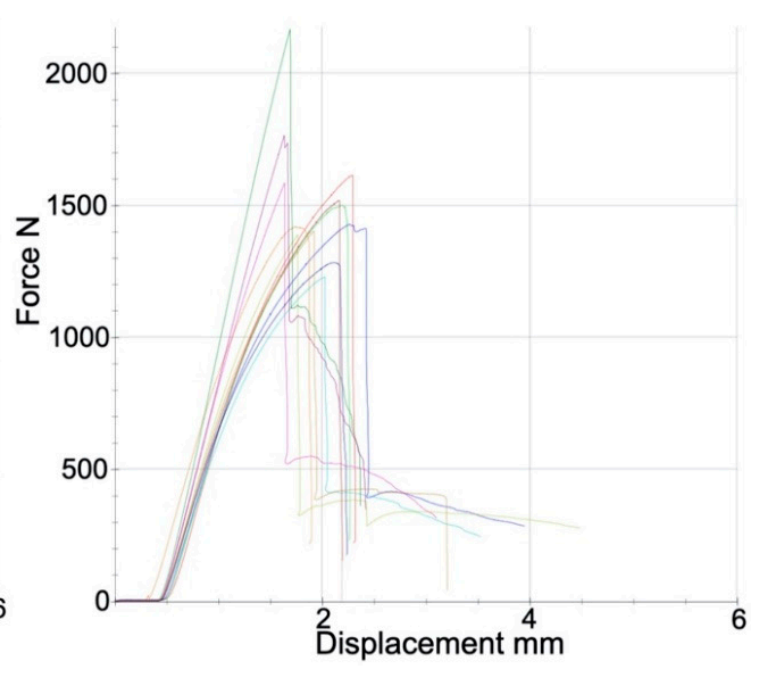

(b)

Figure 4. Force-displacement diagrams. (a) Cobalt-chromium frameworks with ceramic veneering $(\mathrm{Co}-\mathrm{Cr}),(\mathbf{b})$ carbon-fiber framework with resin veneering (CFRC).

The results according to the type of fracture following the chi-squared test (Table 1), revealed a high statistical difference $(p<0.01)$ and a $57 \%$ of effect between the $\mathrm{Co}-\mathrm{Cr}$ group and the CFRC group. Adhesive failure with fully ceramic veneering chipping was reported in $91.7 \%$ of the $\mathrm{Co}-\mathrm{Cr}$ structures and the remaining failures within this group were of a mixed type (8.3\%), (Table 3, Figures 5 and 6 ). On the other hand, $66.7 \%$ of the CFCR specimens presented a mixed-type failure, preserving the resin coating to fiber framework. The rest of the failures in this group were cohesive-type fractures in $16.7 \%$ of the specimens and adhesive in the remaining 16.7\% (Figure 6).

Table 3. Inferential analysis: difference between percentages. Percentages of the different types of fracture produced depending on the groups. Adhesive-type fractures predominate in the Co-Cr group with $91.7 \%$ compared to $66.7 \%$ for the mixed type in the CFRC group.

\begin{tabular}{cccccc}
\hline Failure Type & Co-Cr & CFCR & $\mathbf{X}^{\mathbf{2}}$ & $\mathbf{p}$ & $\mathbf{R}^{\mathbf{2}}$ \\
\hline Cohesive & $0.0 \%$ & $16.7 \%$ & & & \\
Adhesive & $91.7 \%$ & $16.7 \%$ & $13.68^{* *}$ & 0.001 & 0.570 \\
Mixed & $8.3 \%$ & $66.7 \%$ & & & \\
\hline
\end{tabular}

$\mathrm{X}^{2}$ - chi-squared frequencies test; $\mathrm{p}$-statistically significant differences $(\mathrm{p}<0.05) ; \mathrm{R}^{2}$-effect size calculation, ${ }^{* *}$ : Highly significant $\mathrm{p}<0.001$. 
a

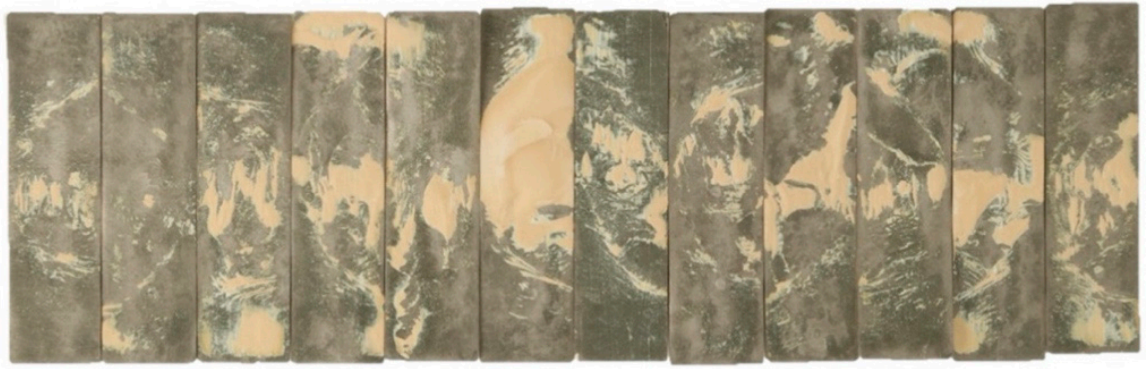

b

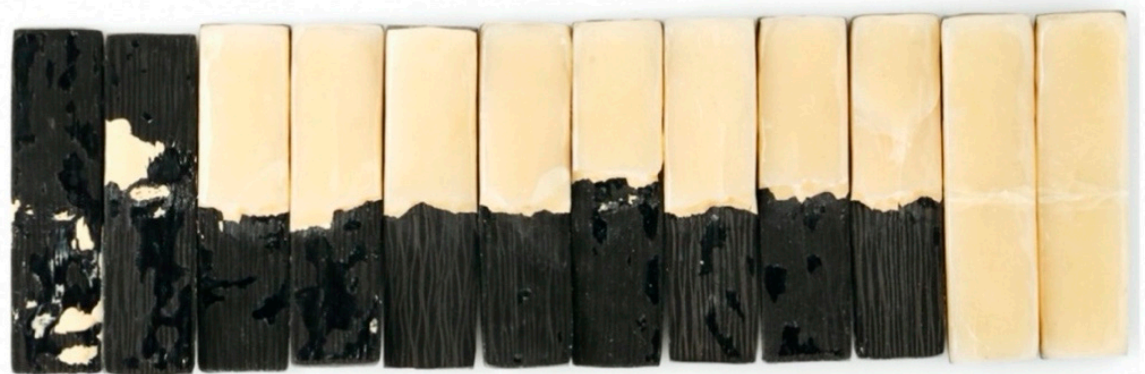

Figure 5. Specimen surface after fracture failures.

(a) Metal-ceramic specimen failures; (b) carbon-fiber-reinforced composite specimen failure.

a

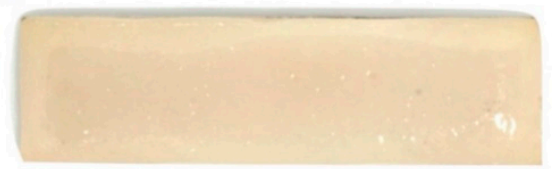

b

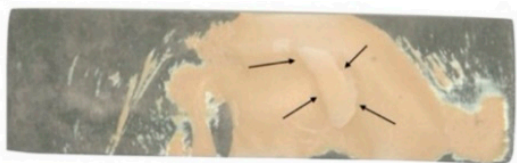

c

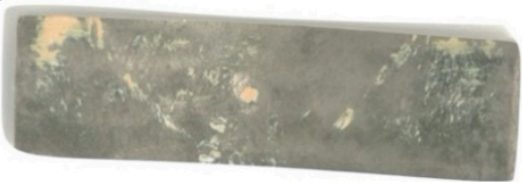

d

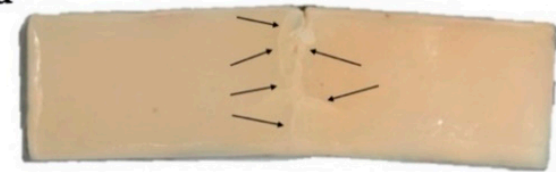

$\mathrm{e}$

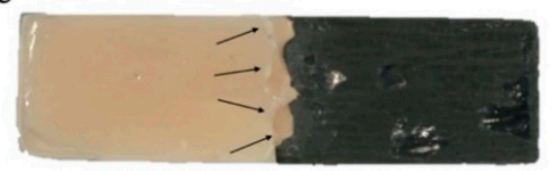

f

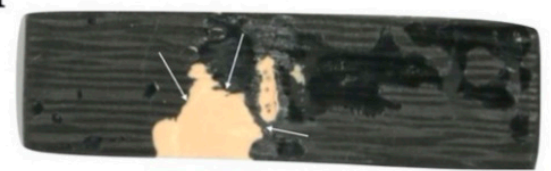

Figure 6. Failure analysis of (a) metal-ceramic specimen before testing; (b) mixed fracture in metal-ceramic specimen; (c) adhesive-type fracture in the metal-ceramic specimen, a complete chipping from the $\mathrm{Co}-\mathrm{Cr}$ structure occurs; (d) cohesive fracture in carbon-fiber reinforced composite specimen, fracture only occurs in the internal layer of the composite resin; (e) mixed fracture in carbon-fiber reinforced composite specimen; (f) adhesive fracture in carbon-fiber reinforced composite specimen, a complete chipping of the coating material from the carbon-fiber framework occurs.

\section{Discussion}

The literature presents an obvious scarcity of in vitro clinical trials of metal-free restorations, particularly trials of those materials that claim to introduce innovative advantages to the field of prosthetic dentistry. The present study used metal-ceramic restorations as its control group, as according to the literature is the most supported [18-21].

The bending testing used in the present trial has been described as the most effective means of evaluating the fracture resistance of restorations and has been used by various authors in the literature [26-32]. 
Several methods have been used to test bond strength; however, no specific standardized method has been reported to measure this parameter accurately [30,37-45]. Moreover, the methodological heterogeneity reported in the literature in terms of the geometric forms of testing, as well as in the distribution of forces, result in differences in the bond strengths obtained among studies [41-45].

Nevertheless, the ANSI/ADA specification No. 38 and ISO 9693 [46] recommend the use of a three-point bending test to evaluate the strength of the metal-ceramic bonding in the same way as ISO 14125:1998 [36] for fiber-reinforced plastic compounds [26,32,45,47]. The 3-point bending test best simulates clinical scenarios; therefore, it was the test of choice in this study to evaluate the bonding strength between the groups.

The purpose of this in vitro study was to compare the bond strength and fracture behavior between $\mathrm{Co}-\mathrm{Cr}$ with ceramic veneering and CFCR. Considering the obtained results, the first null hypothesis was rejected, as statistically significant differences in the bond strength between the $\mathrm{Co}-\mathrm{Cr}$ and CFRC groups were revealed. Likewise, the second null hypothesis was also rejected, as significant differences were observed for the failure types analysis between $\mathrm{Co}-\mathrm{Cr}$ and CFRC.

Although the $\mathrm{Co}-\mathrm{Cr}$ specimens revealed a higher bonding strength than the CFRC group, these results differ from other studies that reported higher values in metal-ceramic specimens [38,39,47-49].

On the other hand, to the best of our knowledge, no previous studies have reported shear bond strength testing values for CFRC. Therefore, these results cannot be directly compared due the lack of homogeneity in methodology [50].

Among the factors that determine bonding strength between surfaces, it has been reported that they could depend on the primary components of the materials [30,51]. For metal-ceramic restorations, bonding is affected by the composition and the thickness of the oxide film that forms on the metal surface. When this layer is absent, thin or thick, the resulting bond strength will be weak $[30,37-39,41,52,53]$. It has been reported that the morphology of the oxidation layer will depend on the techniques used in the manufacturing of $\mathrm{Co}-\mathrm{Cr}$ frameworks $[39,53,54]$. Few preclinical or clinical studies evaluating the behavior of carbon fiber and composite exist, however, the same organic nature of its components has been reported and theoretically presents a better chemical bond. On the other hand, in terms of mechanical retention, sandblasting with aluminum oxide particles is used to increase the contact surface between materials, thus improving mechanical retention and wettability [30,49].

The particle size and material for particle abrasion has been the outcome studied by some authors, who have decided to maintain the size at $110 \mu \mathrm{m}$ in accordance with the methodology of this study [49].

No literature has been found on the mechanical bond between CFRC and composite resin either. The fractures that occur between two materials could be classified as adhesive, cohesive and mixed fractures $[30,55]$. A cohesive failure indicates that the bond between the framework material and the overlay material is stronger than both materials independently and therefore more force will need to be applied to separate these materials $[39,41]$.

As shown in Figure 2, visual and optical microscopy results of the debonding surfaces reveal a direct relationship between the failure type and the different groups studied. The $\mathrm{Co}-\mathrm{Cr}$ group presented adhesive failures in $91.7 \%$ of the specimens, producing leap-type fractures of the ceramic until the total chipping. This failure between the $\mathrm{Co}-\mathrm{Cr}$ framework interface and the ceramic veneering could be influenced by the physicochemical properties of both materials, by the mechanical preparation of the surface as well as by the properties of the applied adhesive [56].

These results are not consistent with those reported in the literature, where the type of fractures in metal-ceramic restorations are described when comparing the metal surface treatments [37] or different fabrication techniques such as casting, milling and selective laser melting [30,38,41,48]. Similarly, mixed fractures, in which $50 \%$ or more of the resin coating remained, were predominant in the CFRC group. One of the advantages of these polymeric materials is the ability to be intraoral repair capacity, in contrast to metal-ceramic restorations, which in many cases require the removal of the prosthesis and reveneering. The repairmen process success will depend on the bond strength between the old and new repair compound, the chipping or fracture extension and the surface mechanical preparation. 
Aging and water absorption lead to degradation of the inhibited oxygen layer, which is necessary for bonding between the two layers [56,57]. To solve this problem, it has been proposed to perform both a mechanical (sandblasting with aluminum oxide, bur abrasion, acid etching and laser irradiation) and a chemical one (application of bonding resin and silane) of the surface to be repaired. Although these techniques have been described, there is currently no consensus on the protocol to follow [58-60].

Comparing results regarding bonding strength, metal-ceramic specimens reported better data. These results are not in the same line with those obtained in a similar study by Taufall et al. who described better results in carbon-resin composite fiber specimens as well as in the carbon-resin acrylic fiber. This difference may have been due to the use of different bond strength testing methods [50].

The present study showed the main limitation of in vitro studies, since the obtained data cannot always be clinically extrapolated. The study was innovative, as it proposes a new material for prosthetic restorations. In vitro and in vivo studies are needed to evaluate the behavior of composite resin to carbon-fiber restorations.

Based on the obtained results from this translational study model, future research with a larger sample and new different $\mathrm{CAD} / \mathrm{CAM}$ materials could provide more power and information to compare. Moreover, clinical studies based on this comparative model for tooth and implant-supported fixed restorations are necessary to be able to refute the data in a clinical human model.

\section{Conclusions}

Based on the findings of this in vitro study the following conclusions were drawn.

1. The cobalt-chrome/ceramic group showed greater bonding strength compared to the carbon-fiber-reinforced composite.

2. While in the carbon-fiber-reinforced composite group, most fractures were mixed or cohesive types, presenting a greater possibility of clinical repair, in the cobalt-chrome/ceramic group fractures, where most had no possibility of direct clinical repair.

Author Contributions: Conceptualization, R.C.-S., P.M.-M. and M.G.-P.; methodology, R.C.-S. and M.G.-P.; software, R.C.-S. and R.A.-P.; validation, R.A.-P.; formal analysis, R.C.-S. and P.M.-M.; investigation, R.C.-S. and P.M.-M.; resources, M.G.-P. and J.D.R.H.; data curation, R.C.-S., P.M.-M. and R.O.; writing-original draft preparation, R.C.-S. and P.M.-M.; writing-review and editing, R.C.-S., P.M.-M., R.A.-P., J.D.R.H. and M.G.-P.; visualization, R.O.; supervision, M.G.-P. and J.D.R.H.; project administration, M.G.-P. and J.D.R.H.; funding acquisition, M.G.-P. and J.D.R.H. All authors have read and agreed to the published version of the manuscript.

Funding: This research received no external funding.

Acknowledgments: The authors would like to thank to Gonzalo Gómez for his assistance during this study, Alberto Cervera for providing the testing methods, Miriam Montero for the testing assessment, Olga San Román and team for the design and manufacturing of the specimens, José Manuel García de Cecilia for performing the statistical analysis and Isabel González Moya and Alexandra Helm for her assistance in this study.

Conflicts of Interest: The authors declare no conflict of interest.

\section{References}

1. Menini, M.; Pesce, P.; Pera, F.; Barberis, F.; Lagazzo, A.; Bertola, L. Biological and mechanical characterization of carbon fiber frameworks for dental implant applications. Mater. Sci. Eng. C 2017, 70, 646-655. [CrossRef] [PubMed]

2. Sharma, M.; Gao, S.; Mäder, E.; Sharma, H.; Wei, L.Y.; Bijwe, J. Carbon fiber surfaces and composite interphases. Compos. Sci. Technol. 2014, 102, 35-50. [CrossRef]

3. Donnet, J.B.; Bansal, R.C. Carbon Fibers; Marcel Dekker: New York, NY, USA, 1990. [CrossRef]

4. Chand, S. Review carbon fibers for composites. J. Mater. Sci. 2000, 35, 1303-1313. [CrossRef]

5. Rajzer, I.; Menaszek, E.; Bacakova, L.; Rom, M.; Blazewicz, M. In vitro and in vivo studies on biocompatibility of carbon fibres. J. Mater. Sci. Mater. Med. 2010, 21, 2611-2622. [CrossRef]

6. Petersen, R. Carbon fiber biocompatibility for implants. Fibers 2016, 4, 1. [CrossRef] 
7. Schmitter, M.; Mueller, D.; Rues, S. In vitro chipping behaviour of all-ceramic crowns with a zirconia framework and feldspathic veneering: Comparison of CAD/CAM-produced veneer with manually layered veneer. J. Oral Rehabil. 2013, 40, 519-525. [CrossRef]

8. Schmitter, M.; Mueller, D.; Rues, S. Chipping behaviour of all-ceramic crowns with zirconia framework and CAD/CAM manufactured veneer. J. Dent. 2012, 40, 154-162. [CrossRef]

9. Pera, F.; Pesce, P.; Solimano, F.; Tealdo, T.; Pera, P.; Menini, M. Carbon fibre versus metal framework in full-arch immediate loading rehabilitations of the maxilla-a cohort clinical study. J. Oral Rehabil. 2017, 44, 392-397. [CrossRef] [PubMed]

10. Tealdo, T.; Menini, M.; Bevilacqua, M.; Pera, F.; Pesce, P.; Signori, A.; Pera, P. Inmediate versus delayed loading of dental implants in edentulous patients' maxillae: A 6-year prospective study. Int. J. Prosthodont. 2014, 27, 207-214. [CrossRef]

11. Hämmerle, C.H.; Wagner, D.; Brägger, U.; Lussi, A.; Karayiannis, A.; Joss, A. Threshold of tactile sensitivity perceived with dental endosseous implants and natural teeth. Clin. Oral Implants Res. 1995, 6, 83-90. [CrossRef] [PubMed]

12. Scurria, M.S.; Bader, J.D.; Shugars, D.A. Meta-analysis of fixed partial denture survival protheses and abutment. J. Prosthet. Dent. 1998, 79, 459-464. [CrossRef]

13. Papaspyridakos, P.; Mokti, M.; Chen, C.J.; Chen, C.J.; Benic, G.I.; Gallucci, G.O.; Chronopoulos, V. Implant and prosthodontic survival rates with implant fixed complete dental prostheses in the edentulous mandible after at least 5 years: A systematic review. Clin. Implants Dent. Relat. Res. 2014, 16, 705-717. [CrossRef]

14. Papaspyridakos, P.; Bordin, T.B.; Natto, Z.S.; Kim, Y.J.; El-Rafie, K.; Tsigarida, A.; Chochlidakis, K.; Weber, H.P. Double full-arch fixed implant-supported prostheses: Outcomes and complications after a mean follow-up of 5 years. J. Prosthodont. 2019, 28, 387-397. [CrossRef] [PubMed]

15. Ucar, Y.; Aksahin, Z.; Kurtoglu, C. Metal ceramic bond after multiple castings of base metal alloy. J. Prosthet. Dent. 2009, 102, 165-171. [CrossRef]

16. Lee, D.; Lee, B.; Kim, S.; Lee, K. Shear bond strength of porcelain to a new millable alloy and a conventional castable alloy. J. Prosthet. Dent. 2015, 113, 329-335. [CrossRef]

17. Nesse, H.; Ulstein, D.M.Å.; Vaage, M.M.; Øilo, M. Internal and marginal fit of cobalt-chromium fixed dental prostheses fabricated with 3 different techniques. J. Prosthet. Dent. 2015, 114, 686-692. [CrossRef]

18. Ortorp, A.; Ascher, A.; Svanborg, P. A 5-year retrospective study of cobalt-chromium-based single crowns inserted in a private practice. Int. J. Prosthodont. 2012, 25, 480-483.

19. Walton, T.R. A 10-year longitudinal study of fixed prosthodontics: Clinical characteristics and outcome of single-unit metal-ceramic crowns. Int. J. Prosthodont. 1999, 12, 519-526. [CrossRef]

20. Pjetursson, B.E.; Asgeirsson, A.G.; Zwahlen, M.; Sailer, I. Improvements in implant dentistry over the last decade: Comparison of survival and complication rates in older and newer publications. Int. J. Oral Maxillofac. Implants 2014, 29, 308-324. [CrossRef]

21. Brägger, U.; Aeschlimann, S.; Bürgin, W.; Hämmerle, C.H.; Lang, N.P. Biological and technical complications and failures with fixed partial dentures (FPD) on implants and teeth after four to five years of function. Clin. Oral Implants Res. 2001, 12, 26-34. [CrossRef]

22. Brägger, U.; Karoussis, I.; Persson, R.; Pjetursson, B.E.; Salvi, G.; Lang, N. Technical and biological complications/failures with single crowns and fixed partial dentures on implants: A 10-year prospective cohort study. Clin. Oral Implants Res. 2005, 16, 326-334. [CrossRef] [PubMed]

23. Pjetursson, B.E.; Tan, K.; Lang, N.P.; Brägger, U.; Egger, M.; Zwahlen, M. A systematic review of the survival and complication rates of fixed partial dentures (FPDs) after an observation period of at least 5 years. Clin. Oral Implants Res. 2004, 15, 625-642. [CrossRef] [PubMed]

24. Pjetursson, B.E.; Brägger, U.; Lang, N.P.; Zwahlen, M. Comparison of survival and complication rates of tooth-supported fixed dental prostheses (FDPs) and implant-supported FDPs and single crowns (SCs). Clin. Oral Implants Res. 2007, 18, 97-113. [CrossRef] [PubMed]

25. Kreissl, M.E.; Gerds, T.; Muche, R.; Heydecke, G.; Strub, J. Technical complications of implant-supported fixed partial dentures in partially edentulous cases after an average observation period of 5 years. Clin. Oral Implants Res. 2007, 18, 720-726. [CrossRef]

26. Joias, R.M.; Tango, R.N.; Junho de Araujo, J.E.; Junho de Araujo, M.A.; Ferreira, G.S.; Paes-Junior, T.J. Shear bond strength of a ceramic to Co-Cr alloys. J. Prosthet. Dent. 2008, 99, 54-59. [CrossRef] 
27. Bader, J.D.; Rozier, R.G.; McFall, W.T.; Ramsey, D.L. Effect of crown margins on periodontal conditions in regularly attending patients. J. Prosthet. Dent. 1991, 65, 75-79. [CrossRef]

28. Felton, D.A.; Kanoy, B.E.; Bayne, S.C.; Wirthman, G.P. Effect of in vivo crown margin discrepancies on periodontal health. J. Prosthet. Dent. 1991, 65, 357-364. [CrossRef]

29. Hammad, I.A.; Talic, Y.F. Designs of bond strength tests for metal-ceramic complexes: Review of the literature. J. Prosthet. Dent. 1996, 75, 602-628. [CrossRef]

30. Lawaf, S.; Nasermostofi, S.; Afradeh, M.; Azizi, A. Comparison of the bond strength of ceramics to Co-Cr alloys made by casting and selective laser melting. J. Adv. Prosthodont. 2017, 9, 52-56. [CrossRef]

31. Segerström, S.; Ruyter, I.E. Mechanical and physical properties of carbon-graphite fiber-reinforced polymers intended for implant suprastructures. Dent. Mater. 2007, 23, 1150-1156. [CrossRef]

32. Kul, E.; Aladag, L.; Duymus, Z.Y. Comparison of the metal-ceramic bond after recasting and after laser sintering. J. Prosthet. Dent. 2015, 114, 109-113. [CrossRef] [PubMed]

33. International Organization for Standardization ISO 178:2010. Dentistry-Plastics-Determination of Flexural Properties; International Organization for Standardization: Geneva, Switzerland, 2010; Available online: https://www.iso.org/standard/45091.html (accessed on 15 July 2020).

34. Scheftner Dental Alloys Web Page. Available online: https://scheftner.dental/starbond-easy-disc-en.html (accessed on 15 July 2020).

35. International Organization for Standardization ISO TS 11405:2015. Dentistry-Testing of Adhesion to Tooth Structure; International Organization for Standardization: Geneva, Switzerland, 2015; Available online: https://www.iso.org/standard/62898.html (accessed on 15 July 2020).

36. International Organization for Standardization ISO TS 14125:1998. Dentistry-Fibre-Reinforced Plastic Composites-Determination of Flexural Properties; International Organization for Standardization: Geneva, Switzerland, 1998; Available online: https://www.iso.org/standard/23637.html (accessed on 15 July 2020).

37. Yan, X.; Xu, Y.; Wu, Y.; Lin, H. Effects of heat treatment on metal-ceramic combination of selective-laser-melted cobalt-chromium alloy. J. Prosthet. Dent. 2018, 120, e1-e6. [CrossRef] [PubMed]

38. Li, J.; Chen, C.; Liao, J.; Liu, L.; Ye, X.; Lin, S. Bond strengths of porcelain to cobalt-chromium alloys made by casting, milling, and selective laser melting. J. Prosthet. Dent. 2017, 118, 69-75. [CrossRef]

39. Wang, H.; Feng, Q.; Li, N.; Xu, S. Evaluation of metal-ceramic bond characteristics of three dental Co-Cr alloys prepared with different fabrication techniques. J. Prosthet. Dent. 2016, 116, 916-923. [CrossRef] [PubMed]

40. Xiang, N.; Xin, X.; Chen, J.; Wei, B. Metal-ceramic bond strength of Co-Cr alloy fabricated by selective laser melting. J. Dent. 2012, 40, 453-457. [CrossRef]

41. Kaleli, N.; Saraç, D. Comparison of porcelain bond strength of different metal frameworks prepared by using conventional and recently introduced fabrication methods. J. Prosthet. Dent. 2017, 118, 76-82. [CrossRef] [PubMed]

42. Anusavice, K.J.; Dehoff, P.H.; Fairhurst, C.W. Comparative evaluation of ceramic-metal bond tests using finite element stress analysis. J. Dent. Res. 1980, 59, 608-613. [CrossRef]

43. Della Bona, A.; Van Noort, R. Shear vs. tensile bond strength of resin composite bonded to ceramic. J. Dent. Res. 1995, 74, 1591-1596. [CrossRef]

44. Papazoglou, E.; Brantley, W.A. Porcelain adherence vs force to failure for palladium-gallium alloys: A critique of metal-ceramic bond testing. Dent. Mater. 1998, 14, 112-119. [CrossRef]

45. Sadeq, A.; Cai, Z.; Woody, R.D.; Miller, A.W. Effects of interfacial variables on ceramic adherence to cast and machined commercially pure titanium. J. Prosthet. Dent. 2003, 90, 10-17. [CrossRef]

46. International Organization for Standardization ISO 9693-1. Dentistry- Compatibility Testing: Part 1: Metal-Ceramic Systems; International Organization for Standardization: Geneva, Switzerland, 2012; Available online: https://www.iso.org/standard/54946.html (accessed on 15 July 2020).

47. Ren, X.; Zeng, L.; Wei, Z.; Xin, X.; Wei, B. Effects of multiple firings on metal-ceramic bond strength of Co-Cr alloy fabricated by selective laser melting. J. Prosthet. Dent. 2016, 115, 109-114. [CrossRef] [PubMed]

48. Ekren, O.; Ozkomur, A.; Ucar, Y. Effect of layered manufacturing techniques, alloy powders, and layer thickness on metal-ceramic bond strength. J. Prosthet. Dent. 2018, 119, 481-487. [CrossRef] [PubMed]

49. Nageshraj, R.; Rajagopal, M.P.; Madapathy, S.; Samuel, P.; Ramabhadran, N.; Mathew, J. An in vitro comparative evaluation of shear bond strengths of veneering porcelain and different core materials. J. Contemp. Dent. Pract. 2018, 19, 1437-1443. [CrossRef] [PubMed] 
50. Menini, M.; Pera, F.; Barberis, F.; Rosenberg, G.; Bagnascoa, F.; Pesce, P. Evaluation of adhesion between carbon fiber frameworks and esthetic veneering materials. Int. J. Prosthodont. 2018, 31, 453-455. [CrossRef] [PubMed]

51. Vásquez, V.Z.; Ozcan, M.; Kimpara, E.T. Evaluation of interface characterization and adhesion of glass ceramics to commercially pure titanium and gold alloy after thermal- and mechanical-loading. Dent. Mater. 2009, 25, 221-231. [CrossRef] [PubMed]

52. Li, J.; Ye, X.; Li, B.; Liao, J.; Zhuang, P.; Ye, J. Effect of oxidation heat treatment on the bond strength between a ceramic and cast and milled cobalt-chromium alloys. Eur. J. Oral Sci. 2015, 123, 297-304. [CrossRef]

53. Serra-Prat, J.; Cano-Batalla, J.; Cabratosa-Termes, J.; Figueras-Àlvarez, O. Adhesion of dental porcelain to cast, milled, and laser-sintered cobalt-chromium alloys: Shear bond strength and sensitivity to thermocycling. J. Prosthet. Dent. 2014, 112, 600-605. [CrossRef]

54. Akova, T.; Ucar, Y.; Tukay, A.; Balkaya, M.C.; Brantley, W.A. Comparison of the bond strength of laser-sintered and cast base metal dental alloys to porcelain. Dent. Mater. 2008, 24, 1400-1404. [CrossRef]

55. Taufall, S.; Eichberger, M.; Schmidlin, P.R.; Stawarczyk, B. Fracture load and failure types of different veneered polyetheretherketone fixed dental prostheses. Clin. Oral Investig. 2016, 20, 2493-2500. [CrossRef]

56. Cavalcanti, A.N.; De Lima, A.F.; Peris, A.R.; Mitsui, F.H.; Marchi, G.M. Effect of surface treatments and bonding agents on the bond strength of repaired composites. J. Esthet. Restor. Dent. 2007, 19, 90-98. [CrossRef]

57. Jafarzadeh Kashi, T.S.; Erfan, M.; Rakhshan, V.; Aghabaigi, N.; Tabatabaei, F.S. An in vitro assessment of the effects of three surface treatments on repair bond strength of aged composites. Oper. Dent. 2011, 36, 608-617. [CrossRef] [PubMed]

58. Gupta, S.; Parolia, A.; Jain, A.; Kundabala, M.; Mohan, M.; De Moraes Porto, I.C. A comparative effect of various surface chemical treatments on the resin composite-composite repair bond strength. J. Indian Soc. Pedod. Prev. Dent. 2015, 33, 245-249. [CrossRef] [PubMed]

59. Kimyai, S.; Mohammadi, N.; Navimipour, E.J.; Rikhtegaran, S. Comparison of the effect of three mechanical surface treatments on the repair bond strength of a laboratory composite. Photomed. Laser Surg. 2010, 28, 25-30. [CrossRef] [PubMed]

60. Nassoohi, N.; Kazemi, H.; Sadaghiani, M.; Mansouri, M.; Rakhshan, V. Effects of three surface conditioning techniques on repair bond strength of nanohybrid and nanofilled composites. Dent. Res. J. 2015, 12, 554-561. [CrossRef]

(C) 2020 by the authors. Licensee MDPI, Basel, Switzerland. This article is an open access article distributed under the terms and conditions of the Creative Commons Attribution (CC BY) license (http://creativecommons.org/licenses/by/4.0/). 